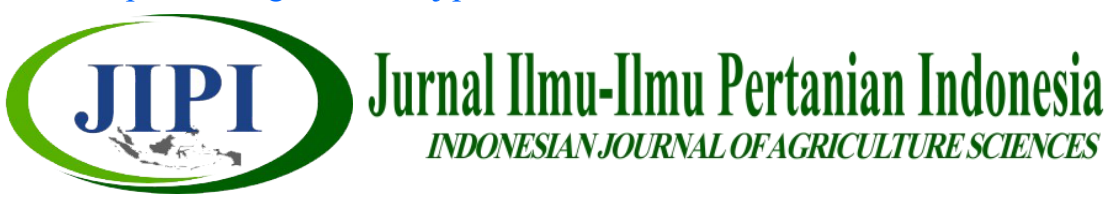

\title{
PERTUMBUHAN DAN HASIL TANAMAN MELON (Cucumis melo L.) PADA KOMPOSISI MEDIA TANAM DAN FREKUENSI PEMUPUKAN YANG BERBEDA
}

\author{
Muhammad Iqbal ${ }^{1}$, M. Faiz Barchia ${ }^{2 *}$, Atra Romeida ${ }^{1}$ \\ ${ }^{1}$ Program Studi Agroekoteknologi, Fakultas Pertanian Universitas Bengkulu \\ ${ }^{1}$ Program Studi Ilmu Tanah, Fakultas Pertanian Universitas Bengkulu \\ * Corresponding Author : faizbarchia@unib.ac.id
}

\begin{abstract}
[GROWTH AND YIELD OF MELON PLANT (Cucumis melo L.) IN DIFFERENT COMPOSITION OF PLANT MEDIA AND DIFFERENT FREQUENCY OF NPK APPLICATION]. This study aims to determine the best combination of planting media composition and frequency of NPK fertilization on the growth and yield of melon plants. The research was conducted in October 2018 - January 2019 on the land located in Bentiring, Muara Bangkahulu District, Bengkulu City. The design used in this study was a Completely Randomized Design (CRD) consisting of two factors and three replications. The first factor was the composition of the media for plant growth, which consists of three different media composition, namely: sand: soil: manure (30\%: 50\%: 20\%), sand: soil: manure (10\%: 60\%: 30\%), and sand: soil: manure (20\%: 70\%: $10 \%)$. The second factor is the frequency of NPK fertilization consisting of four types of fertilization, namely: 1 time NPK fertilization during planting, 2 times NPK fertilization during planting and 10 days after planting (dap), 3 times NPK fertilization during planting, 10 dap and 20 dap, and 4 times NPK fertilizing during planting, 10 dap, 20 dap and 30 dap. The dose given is $15 \mathrm{~g} /$ plant (equivalent to $800 \mathrm{~kg} / \mathrm{ha}$ ) and NPK fertilizer given in the form of compound fertilizer N: P: K 16:16:16. The results showed that the best composition of the planting media was found in the treatment of sand media: soil: manure (10\%: $60 \%: 30 \%)$. The best fertilizing frequency was found in the treatment of NPK fertilizing 4 times during planting, 10 dap, 10 dap, 30 dap, and the combination of both produces the most substantial plant length, weight, and fruit circumference.
\end{abstract}

Keyword: fertilizing frequency, the composition of the planting media, melons

\begin{abstract}
ABSTRAK
Penelitian ini bertujuan untuk menentukan kombinasi komposisi media tanam dan frekuensi pemupukan NPK yang terbaik terhadap pertumbuhan dan hasil tanaman melon. Penelitian telah dilaksanakan pada bulan Oktober 2018 Januari 2019 di lahan yang terletak di Bentiring Kecamatan Muara Bangkahulu, Kota Bengkulu. Disain yang digunakan pada penelitian ini ialah Rancangan Acak Lengkap (RAL) yang terdiri atas dua faktor dan tiga ulangan. Faktor pertama adalah komposisi media tanam, yang terdiri atas tiga jenis komposisi media yaitu : pasir:tanah:pupuk kandang (30\%:50\%:20\%), pasir:tanah:pupuk kandang (10\%:60\%:30\%), dan pasir:tanah:pupuk kandang (20\%:70\%:10\%). Faktor yang kedua adalah frekuensi pemupukan NPK yang terdiri atas empat macam pemupukan yaitu : 1 kali pemupukan NPK saat penanaman, 2 kali pemupukan NPK saat tanam dan 10 hari setelah tanam (hst), 3 kali pemupukan NPK saat tanam, $10 \mathrm{hst}$ dan 20 hst, dan 4 kali pemupukan NPK saat tanam, 10 hst, 20 hst dan 30 hst. Dosis yang diberikan adalah $15 \mathrm{~g} / \operatorname{tanaman}$ (setara $800 \mathrm{~kg} / \mathrm{ha}$ ) dan pupuk NPK yang diberikan dalam bentuk pupuk majemuk N:P:K 16:16:16. Hasil penelitian menunjukkan bahwa komposisi media tanam terbaik terdapat pada perlakuan media pasir:tanah:pupuk kandang (10\%:60\%:30\%). Frekuensi pemupukan terbaik terdapat pada perlakuan 4 kali pemupukan NPK saat tanam, 10 hst, 20 hst dan 30 hst, dan kombinasi keduanya menghasilkan panjang tanaman, bobot, dan lingkar buah terbesar.
\end{abstract}

Kata kunci: frekuensi pemupukan, komposisi media tanam, melon 


\section{PENDAHULUAN}

Kesadaran masyarakat terhadap gizi yang semakin meningkat, mengakibatkan permintaan buah-buahan terutama buah melon mengalami peningkatan. Melon merupakan salah satu jenis tanaman hortikultura yang sampai saat ini banyak dikonsumsi oleh masyarakat, karena memiliki kandungan gula, lycopene dan air yang tinggi. Kandungan yang ada di dalam $100 \mathrm{~g}$ buah melon yaitu protein $0,6 \mathrm{~g}$, kalsium $17 \mathrm{mg}$, thiamin $0,045 \mathrm{mg}$, vitamin A 2,4 IU, vitamin C $30 \mathrm{mg}$, vitamin B 0,045 mg, vitamin B2 0,065 mg, karbohidrat $6 \mathrm{mg}$, niasin $1 \mathrm{mg}$, riboflavin $0,065 \mathrm{mg}$, zat besi $0,4 \mathrm{mg}$, nikotianida $0,5 \mathrm{mg}$, air $93 \mathrm{~mL}$, serat $0,4 \mathrm{~g}$, dan kalori sebanyak 23 kalori (Siswanto, 2010).

Data produksi buah nasional menunjukkan bahwa produksi buah di Indonesia masih tergolong rendah. Salah satu masalahnya adalah benih unggul buatan Indonesia yang belum cukup tersedia. Buah melon termasuk dalam golongan buah yang produksinya rendah. Produksi melon di Indonesia pada tahun 2013 mencapai 125.207 ton dan meningkat pada tahun 2014 menjadi 150.356 ton, dan pada tahun 2015 terjadi penurunan produksi menjadi 137.887 ton. Sedangkan di Provinsi Bengkulu pada tahun 2014 produksi melon mencapai 142 ton, dan pada tahun 2015 menurun drastis menjadi 40 ton (Badan Pusat Statistik, 2017).

Pemberian bahan organik dan pupuk anorganik (N, P dan K) merupakan suatu usaha untuk memenuhi kebutuhan hara bagi tanaman. Fungsi bahan organik adalah memperbaiki struktur tanah, menambah ketersediaan unsur $\mathrm{N}, \mathrm{P}$ dan $\mathrm{K}$, meningkatkan kemampuan tanah mengikat air, memperbesar kapasitas tukar kation (KTK) dan mengaktifkan mikroorganisme (Leiwakabessy et al., 2003).

Tanaman melon dapat tumbuh dengan baik bila $\mathrm{pH}$ atau keasaman tanah antara 5,8-7,8. Pada keadaan fisik, biologi dan kimia tanah yang kurang menguntungkan bagi tanaman melon maka penambahan pupuk kandang dapat menjadi salah satu alternatif dalam memperbaki sifatsifat tanah tersebut agar lebih baik untuk pertumbuhan tanaman melon.

Media tanam dapat didefinisikan sebagai kumpulan bahan atau substrat tempat tumbuh benih yang disebarkan atau ditanam. Media tanam dapat merupakan campuran dari bermacam-macam bahan atau satu jenis bahan saja asalkan memenuhi beberapa persyaratan, antara lain cukup baik dalam memegang air, bersifat mudah menyerap sehingga air siraman tidak menggenang, dan tidak bersifat toksik (racun) bagi tanaman. Media tanam tersebut juga cukup mengandung unsur-unsur hara yang diperlukan bagi pertumbuhan tanaman. Media tanam dapat diperbaiki dengan pemberian bahan organik seperti kompos, pupuk kandang atau bahan organik lain (Suteja \& Kartasapoetra, 1992). Kandungan pasir dalam media tanam dapat berfungsi untuk membantu mempercepat air masuk ke dalam tanah.

Indonesia memiliki luas dataran Ultisol sekitar $25 \%$ dari total luas dataran yang ada yaitu 45.794 .000 ha (Subagyo et al., 2000). Ultisol dikategorikan tidak produktif, karena pada umumnya tanah ini miskin kandungan bahan organik (Bertham, 2002). Tanah ini juga miskin kandungan hara terutama $\mathrm{P}$ dan kation-kation yang dapat dipertukarkan seperti $\mathrm{Ca}, \mathrm{Mg}$, Na, dan $\mathrm{K}$ (Hardjowigeno, 2003). Reaksi tanah masam hingga sangat masam dengan pH 3-5 (Prasetyo et al., 2006). Ketersediaan P rendah disebabkan terfiksasi liat, $\mathrm{Al}$ dan $\mathrm{Fe}$ membentuk Al-P dan Fe-P yang sukar larut sehingga tidak dapat dimanfaatkan oleh tanaman (Hakim et al., 1986).

Tanah pasir dicirikan bertekstur pasir, struktur berbutir, konsistensi lepas, sangat poros, sehingga daya sangga air dan hara sangat rendah (Pusat Penelitian Tanah dan Agroklimat, 1994), miskin hara dan kurang mendukung pertumbuhan tanaman (Bertham et al., 2018) Tekstur tanah pasir ini sangat berpengaruh pada status dan distribusi air, sehingga berpengaruh pada sistem perakaran, kedalaman akar, hara dan $\mathrm{pH}$ (Syukur, 2005). Akibat dari sangat rendahnya hara yang terkandung di dalam tanah pasir maka diperlukan upaya pemupukan pada media tanah ini.

Penambahan pupuk kandang dapat memperbaiki lingkungan tumbuh tanaman yang dapat meningkatkan efisiensi pupuk termasuk memperbaiki sifat fisik, kimia dan biologi tanah (Arafah et al., 2003). Pupuk kandang dapat meningkatkan unsur hara baik makro maupun mikro, memperbaiki struktur tanah, meningkatkan daya pegangan air, meningkatkan kapasistas tukar kation dan memacu aktivitas mikroorganisme yang terlibat dalam proses perombakan hara tidak tersedia menjadi hara tersedia (Muhidin, 2000).

Tanaman dapat memanfaatkan semaksimal mungkin unsur hara dari pupuk melalui minimalisasi pencucian dan penguapan. Salah satu upaya yang dilakukan untuk menghindari penguapan dan pencucian pupuk adalah melakukan pemupukan yang berulang, atau mengatur frekuensi pemupukan pada tanaman. Keberhasilan pemupukan juga ditentukan oleh faktor waktu pemupukan (Damanik et al., 2011). Waktu pemberian haruslah tepat, misalnya pemberian pupuk yang terlalu awal akan membuat pupuk cepat hilang sehingga tidak terserap oleh tanaman, jadi pupuk harus diberikan sehingga saat tanaman membutuhkan unsur hara tersebut tersedia bagi tanaman.

Penelitian ini bertujuan untuk menentukan kombinasi komposisi media tanam dan frekuensi pemupukan NPK yang terbaik terhadap pertumbuhan dan hasil tanaman melon. 


\section{METODE PENELITIAN}

Penelitian ini telah dilaksanakan pada bulan Oktober 2018 - Januari 2019 di lahan yang terletak di Bentiring Kecamatan Muara Bangkahulu Kota Bengkulu. Sampel tanah yang digunakan untuk penelitian ini yaitu tanah yang ada di lahan Medan Baru, Provinsi Bengkulu.

Bahan yang digunakan dalam penelitian ini meliputi benih Melon varietas Madesta fl, polybag, pupuk kandang, pasir dan pupuk majemuk NPK 16:16:16. Alat yang digunakan pada penelitian ini meliputi meteran kain, parang, arit, cangkul, gembor, ember, naungan buatan dan ajir.

Penelitian ini menggunakan Rancangan Acak Lengkap (RAL) dengan dua faktor. Faktor pertama yaitu komposisi media tanam, yang terdiri atas tiga jenis komposisi media yaitu : pasir : tanah : pupuk kandang (30\%:50\%:20\%), pasir : tanah : pupuk kandang (10\%:60\%:30\%), dan pasir : tanah : pupuk kandang (20\%:70\%:10\%) berdasarkan berat. Faktor yang kedua adalah frekuensi pemupukan NPK yang terdiri atas empat frekwensi pemupukan yaitu : 1 kali pemupukan NPK saat penanaman, 2 kali pemupukan NPK saat tanam dan 10 hari setelah tanam (hst), 3 kali pemupukan NPK saat tanam, 10 hst dan 20 hst, dan 4 kali pemupukan NPK saat tanam, 10 hst, 20 hst dan 30 hst. Dosis yang diberikan adalah $15 \mathrm{~g} /$ tanaman (setara $800 \mathrm{~kg} / \mathrm{ha}$ ) dan pupuk NPK yang diberikan dalam bentuk pupuk majemuk N:P:K 16:16:16. Polybag yang digunakan dalam penelitian ini berukuran $40 \mathrm{~cm}$ x $50 \mathrm{~cm}$ yang diisi media tanam sebanyak $10 \mathrm{~kg}$. Dari kedua faktor perlakuan dihasilkan 12 kombinasi perlakuan. Setiap kombinasi perlakuan diulang sebanyak 3 kali sehingga terdapat 36 satuan percobaan. Untuk keperluan penyulaman dipersiapkan 1 ulangan tambahan untuk setiap kombinasi perlakuan sehingga didapatkaan 72 polybag.

Benih Melon dipilih berdasar ukuran yang seragam dengan cara melihat secara fisik ukuran benih tersebut lalu ditanam pada media semai dengan Karbufuran $3 \%$ di dalam polybag berukuran $10 \mathrm{~cm}$ x $15 \mathrm{~cm}$ sebanyak 36 polybag. Bibit dipindah ke polybag berukuran 40 $\mathrm{cm}$ x $50 \mathrm{~cm}$ setelah berumur $2 \mathrm{mst}$. Benih disiram setiap pagi hari (Khumaero et al., 2014).

Tanah yang digunakan merupakan Ultisol yang diambil di lahan sekitar area Medan Baru, Bengkulu pada kedalaman $0-20 \mathrm{~cm}$ di lima titik yang kemudian dikompositkan. Setelah itu tanah dikering anginkan dan diayak kasar dengan ayakan $5 \mathrm{~mm}$. Pasir yang dipakai dalam penelitian ini adalah pasir sungai. Kemudian pupuk kandang yang digunakan adalah pupuk kandang sapi yang diambil dari wilayah zona pertanian terpadu Medan Baru. Lalu ketiga macam media tanam tersebut dimasukkan ke dalam polybag ukuran $40 \mathrm{~cm} \times 50 \mathrm{~cm}$ sesuai dengan perlakuan masing-masing polybag tersebut diberi label dan disusun secara acak. Tanaman melon yang telah berumur 2 mst dipindahkan ke polybag yang masing-masing telah diberi perlakuan yang berbeda. Setiap unit percobaan memiliki 2 tanaman cadangan untuk antisipasi jika ada tanaman yang mati.

Pemupukan NPK dilakukan sesuai dengan perlakuan. Frekwensi pemupukan diaplikasikan sebelum muncul bunga yaitu 24-33 hari setelah tanam (Annisa \& Gustia, 2017). Pemupukan NPK dilakukan dengan dosis yang sama pada setiap media yaitu $15 \mathrm{~g} /$ tanaman.

Pemeliharaan tanaman meliputi penyiraman, pemupukan, pengendalian organisme pengganggu tanaman, pengikatan batang, pemangkasan tunas dan pengikatan buah. Penyiraman dilakukan setiap hari pada pagi hari untuk menjaga kelembaban tanah sehingga unsur hara dapat terlarut dan tersedia untuk tanaman.

Pemanenan buah melon dilakukan dengan menggunakan gunting pada saat buah melon telah memenuhi kriteria panen yaitu memiliki ciri-ciri ukuran buah telah maksimal, buah sudah beraroma harum, jika ada jaring atau net pada buah maka jaring sudah terbentuk merata, ada retakan di sekitar tangkai buah (halfslip dan fullslip).

Analisis tanah dilakukan dengan cara mengambil tanah sebanyak $1 \mathrm{~kg}$ yang telah dikering anginkan dan diayak dengan menggunakan ayakan berukuran $5 \mathrm{~mm}$. Sampel tanah tersebut kemudian dianalisis $\mathrm{pH}$ (Elektrometris), C-Organik (Walkey and Black), P-tersedia (Bray-1), Kdd (Flame Fotometer) dan N-total (Kjeldahl). Variabel tanaman yang diamati meliputi : panjang tanaman, tingkat kehijauan daun, jumlah daun/tanaman, jumlah buah total/tanaman, lingkar buah/tanaman, dan bobot buah/tanaman.

Data yang diperoleh dianalisis dengan uji $\mathrm{F}$ pada taraf 5\%. Perbandingan rata-rata antar perlakuan dilakukan dengan DMRT taraf 5\% (Gomez \& Gomez, 1983).

\section{HASIL DAN PEMBAHASAN}

Suhu udara pada awal tanam pada bulan Oktober sampai Januari rata-rata $27,1{ }^{\circ} \mathrm{C}$. Pada umur $7 \mathrm{hst}$ tanaman mulai menunjukkan pertumbuhan yang baik dengan batang sudah mulai membesar dan daun mulai melebar.

Pada awal masa pertumbuhan, curah hujan terjadi dengan intensitas yang tinggi sehingga dilakukan penanggulangan berupa pembuatan naungan berbahan waring. Naungan berupa waring bertujuan untuk memecah butiran hujan yang besar menjadi lebih kecil, sehingga daya rusaknya lebih kecil, namun tanaman tetap mendapatkan air. Tanaman menunjukkan gejala terserang hama berupa ulat penggerek daun pada umur 2 mst terlihat pada beberapa daun tanaman mesofil daunnya tergores. Kemudian beberapa tepi daun lainnya rusak diduga akibat serangan belalang. Untuk mencegah kerusakan lebih banyak dilakukan penanggulangan dengan pemberian insektisida setiap minggu hingga 
masa panen.Tindakan penanggulangan terlihat cukup berpengaruh ditunjukkan dengan berkurangnya serangan hama tersebut.

Laju pertumbuhan tanaman pada 4 mst terlihat sudah mulai meningkat dibandingkan sebelumnya, ditandai dengan ukuran panjang tanaman, daun, sulur dan batang yang meningkat pesat. Setelah tanaman berumur \pm 6 mst, pengaruh dari faktor waktu pemupukan mulai terlihat, ditandai dengan perbedaan ukuran pada beberapa tanaman yang cukup besar, hal ini terus berlangsung hingga masa panen tiba. Tanah yang digunakan sebagai media tanam memiliki $\mathrm{pH}$ sebesar 4,35, N-total $0,10 \%$, P-tersedia 3,48 ppm, K-dd 0,21 me/100, dan C-Organik 2,52\%.

Hasil analisis keragaman terhadap data yang diperoleh menunjukkan bahwa komposisi media tanam berpengaruh tidak nyata $(\mathrm{P}>0,05)$ terhadap variabel pertumbuhan tanaman, sedangkan frekuensi pemupukan berpengaruh nyata $(\mathrm{P} \leq 0,05)$ terhadap variabel panjang tanaman, bobot buah, dan lingkar buah, namun terdapat interaksi yang tidak nyata antara kedua faktor tersebut.

Hasil penelitian Simanullang et al. (2017) menunjukkan bahwa aplikasi media tanam berpengaruh tidak nyata terhadap pertumbuhan bibit tanaman, namun nilai tertinggi ditunjukkan oleh komposisi dengan jumlah bahan organik terbanyak. Komposisi media tanam berupa pupuk kandang sapi yang belum dikomposkan memiliki kadar $\mathrm{C} / \mathrm{N}$ rasio yang tinggi, menyebabkan $\mathrm{N}$ pada pupuk tersebut tidak tersedia bagi tanaman sehingga pertumbuhan tanaman tidak maksimal (Hartatik \& Widowati, 2006).

Pada perlakuan waktu pemupukan, hasil yang didapatkan bertentangan dengan yang diharapkan, karena pemberian $\mathrm{N}$ umumnya akan berpengaruh terhadap pembentukan daun, dan tingkat kehijauan daun. Jika dibandingkan hasil penelitian Simanungkalit et al. (2013) yang menunjukkan dosis pupuk NPK $45 \mathrm{~g} /$ tanaman dapat meningkatkan panjang sulur dan jumlah daun sebesar 37,6\%. Hal ini wajar saja terjadi, karena dosis pupuk yang jauh lebih kecil pada penelitian ini menyebabkan unsur yang terkandung tidak cukup untuk digunakan pada bagian tanaman yang lain, sehingga pertumbuhannya tidak maksimal.

Interaksi media tanam dengan frekuensi pemupukan berpengaruh tidak nyata terhadap semua variabel pengamatan. Hal ini dapat disebabkan pupuk kandang yang digunakan sebagai salah satu komposisi media tanam masih dalam kondisi yang belum matang. Pupuk kandang diketahui mengandung banyak mikroorganisme yang berfungsi untuk mendekomposisi bahan organik. Namun untuk melakukan dekomposisi, mikroorganisme tersebut membutuhkan enersi. Unsur hara yang terdapat pada pupuk NPK digunakan oleh dekomposer sehingga tidak tersedia lagi bagi tanaman (Setyorini et al., 2006).
Komposisi media tanam berupa $10 \%$ pasir, $60 \%$ tanah dan 30\% pupuk kandang menghasilkan rata-rata bobot dan lingkar buah terbesar dibandingkan dengan komposisi media lainnya. Namun hasil ini berbeda tidak nyata dengan komposisi media tanam 30\% pasir, 50\% tanah dan 20\% pupuk kandang (Tabel 1).

Tabel 1. Rata-rata bobot dan lingkar buah melon pada tiga komposisi media tanam

\begin{tabular}{|c|c|c|}
\hline Media Tanam & $\begin{array}{c}\text { Bobot Buah } \\
\text { (g) } \\
\end{array}$ & $\begin{array}{c}\text { Lingkar Buah } \\
(\mathrm{cm})\end{array}$ \\
\hline $30 \%: 50 \%: 20 \%$ & $557,47 \mathrm{ab}$ & $32,3 \mathrm{ab}$ \\
\hline $10 \%: 60 \%: 30 \%$ & $604,37 \mathrm{a}$ & $34,3 \mathrm{ab}$ \\
\hline $20 \%: 70 \%: 10 \%$ & $526,77 \mathrm{~b}$ & $30,2 \mathrm{~b}$ \\
\hline
\end{tabular}

Keterangan: Angka-angka pada kolom yang sama yang diikuti oleh huruf yang sama menunjukkan berbeda tidak nyata menurut DMRT pada taraf 5\%.

Komposisi media tanam berupa $10 \%$ pasir, $60 \%$ tanah dan 30\% pupuk kandang menghasilkan rata-rata bobot buah terbesar $604,35 \mathrm{~g}$. Hal ini disebabkan karena komposisi takaran pupuk kandang paling tinggi dibandingkan dengan komposisi media lainnya. Pupuk kandang mengandung bahan organik dan unsur-unsur hara esensial yang cukup lengkap walaupun dalam jumlah yang sedikit. Pada dosis yang cukup, kandungan hara dan bahan oganik yang dibutuhkan tanaman dapat dipenuhi, sehingga tanaman mampu memaksimalkan aktivitas metaboliknya. Oleh karena itu wajar jika jumlah cadangan makanan yang dihasilkan oleh melon meningkat, kemudian menyebabkan meningkatnya hasil buah tersebut. Hasil penelitian sebelumnya menunjukkan perilaku yang sama yaitu peningkatan dosis pupuk kandang juga diiikuti dengan meningkatnya hasil selada secara nyata (Evelyn et al., 2018). Rendahnya kandungan pasir (10\%) juga mengakibatkan porositas tanah meloloskan air menjadi rendah sehingga memungkinkan diserap oleh tanaman.

Komposisi media tanam berupa $10 \%$ pasir, $60 \%$ tanah dan 30\% pupuk kandang menghasilkan rata-rata lingkar buah yang paling besar yaitu $34,3 \mathrm{~cm}$ dibandingkan dengan yang dihasilkan komposisi media tanam lainnya. Pemberian pupuk kandang sebagai salah satu komposisi media tanam, menjamin kebutuhan tanaman akan unsur hara esensial bisa terpenuhi walaupun tidak maksimal. Pupuk kandang mengandung sejumlah unsur hara esensial yang komplit, selain bahan organik dan asam-asam organik yang sangat berguna dalam memacu proses metabolisme tanaman. Dengan jumlah yang cukup, maka aktifitas metabolik terpacu dan mampu membentuk lingkar buah yang cukup besar. 
Fraksi pasir yang tinggi menyebabkan tingginya porositas tanah. Porositas yang tinggi menyebabkan tanah tidak mampu menahan air secara maksimal, sehingga tanaman tidak memanfaatkan secara maksimal pula. Peranan air pada tanaman di antaranya yaitu sebagai pelarut unsur hara yang umumnya diserap dalam bentuk larutan tanaman, transportasi fotosintat, menjaga turgiditas sel baik dalam pembesaran sel maupun membukanya stomata, sebagai penyusun utama dari protoplasma serta pengatur suhu bagi tanaman. Apabila ketersediaan air tanah kurang bagi tanaman, maka petumbuhan maupun hasil akan terhambat (Hermawan et al., 2019; Felania, 2017; Maryani, 2012; Song \& Banyo, 2011;).

Komposisi media tanam memberikan pengaruh yang nyata terhadap bobot dan diameter buah melon namun tidak pada variabel pertumbuhan dan jumlah buah melon. Hal ini disebabkan karena komposisi dalam media berupa pupuk kandang mengandung serat tumbuhan yang membutuhkan waktu yang cukup untuk terurai. Oleh karena itu unsur hara yang terkandung di dalamnya membutuhkan waktu yang lama untuk tersedia bagi tanaman (Jamilah, 2002).

Variabel panjang tanaman tumbuh secara nyata, diasumsikan karena akumulasi pemberian NPK walaupun dalam jumlah yang sedikit namun tersedia bagi tanaman, sehingga tanaman dapat memacu pertumbuhan pada bagian meristem apikal salah satunya yaitu ujung batang tanaman. Frekwensi pemupukan dengan interval waktu 4 kali menghasilkan nilai tertinggi $189 \mathrm{~cm}$ tetapi berbeda tidak nyata dengan frekwensi pemberian pupuk 3 kali (Tabel 2). Pemupukan dilakukan secara terus-menerus dari saat tanam hingga saat akhir masa vegetatif. Resiko tercuci maupun penguapan lebih kecil, sehingga kebutuhan tanaman akan unsur $\mathrm{N}$, P, dan K terpenuhi. Pada frekwensi pemupukan 2 dan 1 kali, resiko tercuci dan penguapan lebih besar dibandingkan dengan frekwensi 3 dan 4 kali.

Tabel 2. Pertumbuhan dan hasil melon pada empat frekwensi pemupukan

\begin{tabular}{|l|c|c|c|}
\hline $\begin{array}{l}\text { Frekwensi } \\
\text { Pemupukan }\end{array}$ & $\begin{array}{c}\text { Panjang } \\
\text { Tanaman } \\
(\mathrm{cm})\end{array}$ & $\begin{array}{c}\text { Bobot buah } \\
(\mathrm{g})\end{array}$ & $\begin{array}{c}\text { Lingkar Buah } \\
(\mathrm{cm})\end{array}$ \\
\hline 1 kali & $162,11 \mathrm{~b}$ & $510,90 \mathrm{~b}$ & $29,7 \mathrm{c}$ \\
\hline $2 \mathrm{kali}$ & $156,44 \mathrm{~b}$ & $516,81 \mathrm{~b}$ & $30,6 \mathrm{bc}$ \\
\hline 3 kali & $171,67 \mathrm{ab}$ & $610,77 \mathrm{a}$ & $34 \mathrm{ab}$ \\
\hline 4 kali & $189 \mathrm{a}$ & $613,01 \mathrm{a}$ & $34,8 \mathrm{a}$ \\
\hline
\end{tabular}

Keterangan: Angka-angka pada kolom yang sama yang diikuti oleh huruf yang sama menunjukkan berbeda tidak nyata menurut DMRT pada taraf $5 \%$.

Waktu pemupukan dengan frewensi 4 kali pemupukan menghasilkan bobot buah terberat 613,01 g dibandingkan dengan frekwensi pemupukan 3 kali saat tanam, 10 hst, dan 20 hst. Hasil keduanya berbeda nyata jika dibandingkan dengan frekwensi pemupukan 2 kali ataupun 1 kali (Tabel 2). Jika dilihat dari frekwensi dan intervalnya, pemupukan 2 kali dan 1 kali yang hanya memberikan pupuk pada saat tanam dan $10 \mathrm{hst}$, menyebabkan kebutuhan hara pada awal masa generatif kurang tercukupi. Hal ini sesuai hasil penelitian Simanungkalit et al. (2013) yang menunjukkan pemupukan 22,5 g/tanaman dapat meningkatkan produksi buah/tanaman dan per plot hingga 32,8\% dengan waktu pemupukan pada 30 hst dan 45 hst. Pemberian NPK berpengaruh terhadap bobot buah tanaman melon, karena saat itu tanaman sangat membutuhkan unsur $\mathrm{P}$ dan $\mathrm{K}$ dalam pembungaan dan pembuahan. Oleh karena itu proses pembesaran buah dapat berlangsung lebih maksimal.

Frekwensi pemupukan 4 kali pada saat tanam, 10 hst, 20 hst, dan 30 hst menghasilkan lingkar buah terbesar rata-rata $34,8 \mathrm{~cm}$ namun berbeda tidak nyata frekwensi pemupukan 3 kali yaitu pada saat tanam, 10 hst, dan 20 hst. Hasil ini berbeda nyata jika dibandingkaan dengan frekwensi pemupukan 2 kali dan 1 kali. Berdasarkan hasil tersebut terlihat bahwa frekwensi pemupukan yang pemberiannya berdekatan menghasilkan lingkar buah yang berbeda tidak nyata. Hal ini disebabkan karena interval waktu pemberian yang tetap yakni setiap 10 hari sekali dari saat tanam dan selisih dosis pupuk yang tidak begitu besar pada interval yang berdekatan. Hasil penelitian Luviana et al. (2017) menunjukkan bahwa diameter dan bobot terbaik dihasilkan pada perlakuan interval waktu 1 minggu, disusul interval 2 minggu. Semakin kecil rentang waktu pemupukan semakin baik pula hasilnya, namun dosis dan efisiensi pemupukan tetap harus diperhatikan. Peningkatan bobot buah dan lingkar buah hampir searah, dengan demikian dapat dikatakan lingkar buah tertinggi pada frekwensi pemupukan terjadi karena unsur NPK yang diberikan hingga 30 hst yang merupakan fase pembungaan dan pembuahan akan dimulai. Pemberian NPK saat itu menyebabkan kebutuhan hara terutama $\mathrm{P}$ dan $\mathrm{K}$ yang berperan dalam pembungaan dan pembuahan dapat terpenuhi, sehingga pembentukan buah terjadi secara normal. Dengan demikian lingkar buah juga akan semakin besar.

\section{KESIMPULAN}

Tidak terdapat interaksi media tanam dan frekwensi pemupukan terhadap semua variabel yang diamati. Komposisi media tanam terbaik untuk hasil melon terdapat pada media tanam $10 \%$ pasir, $60 \%$ tanah, dan $30 \%$ pupuk kandang yang menghasilkan bobot buah $604,37 \mathrm{~g}$ dan lingkar buah tertinggi sebesar $34,3 \mathrm{~cm}$. Frekwensi pemupukan terbaik untuk pertumbuhan dan hasil tanaman melon terdapat pada frekwensi pemupukan 3 kali (saat tanam, 10 hst, dan 20 hst) yang menghasilkan panjang tanaman $171,67 \mathrm{~cm}$, bobot $610,01 \mathrm{~g}$ dan lingkar buah terbesar $34 \mathrm{~cm}$. 


\section{DAFTAR PUSTAKA}

Annisa, P. \& Gustia, H. (2017). Respon Pertumbuhan dan Produksi Tanaman Melon Terhadap Pemberian Pupuk Organik Cair Tithonia diversifolia. Prosiding Seminar Nasional 2017. Fakultas Pertanian, Universitas Muhammadiyah Jakarta, Jakarta.

Arafah \& Sirappa, M.P. (2003). Kajian penggunaan jerami dan pupuk N, P dan K pada lahan sawah irigasi. J. Ilmu Tanah dan Lingkungan, 4(1), 15-24.

Badan Pusat Statistik. (2017). Data statistik Melon Provinsi Bengkulu dan Nasional. https: $/ / w w w$. bps.go.id. 30 April 2018.

Bertham, Y.H., Aini, N., Murcitro, B.G. \& Nusantara, A.D. (2018). Uji coba empat varietas kedelai di kawasan pesisir berbasis biokompos. BIOGENESIS Jurnal Ilmiah Biologi, 6(1), 36-42. DOI https://doi. org/10.24252/bio.v6i1.4144.

Bertham,Y.H. (2002). Respon tanaman kedelai (Glycine $\max (\mathrm{L})$ Merill) terhadap pemupukan fosfor dan kompos jerami pada tanah ultisol. Jurnal Ilmuilmu Pertanian Indonesia, 4(2), 78-83.

Damanik, M.M.B., Bachtiar, E.H., Fauzi, Sarifuddin, \& Hamidah, H. (2011). Kesuburan Tanah dan Pemupukan. USU Press., Medan.

Evelyn, Hindarto, K.S. \& Inoriah, E. (2018). Pertumbuhan dan hasil selada (Lactuca sativa L.) dengan pemberian pupuk kandang dan abu sekam padi di Inceptisol. Jurnal Ilmu-ilmu Pertanian Indonesia, 20(2), 46-50. DOI: https://doi.org/10.31186/jipi.20.2. 46-50.

Felania, C. (2017). Pengaruh Ketersediaan Air terhadap Pertumbuhan Kacang Hijau (Phaceolus radiatus). Prosiding Seminar Nasional Pendidikan Biologi dan Biologi. Fakultas MIPA. Universitas Negeri Yogyakarta, Yogyakarta.

Gomez, K.A. \& Gomez, A.A. (1983). Statistical Procedures for Agricultural Research.John Wiley \& Sons., Singapore.

Hakim, N., Nyakpa, M.Y., Lubis, A.M., Nugroho, S.G., Saul, M.R., Diha, M.A., Hong, G.B. \& Bailey, H.H. (1986). Dasar - Dasar Ilmu Tanah. Universitas Lampung, Lampung.

Hardjowigeno, S. 2003. Ilmu Tanah. Akademika Pressindo, Jakarta.

Hartatik, W.\& Widowati, L.R. (2006). PupukKandang In R. D. M. Simanungkalit, D.A. Suniadikarta, R. Saraswati, D. Setyorini, dan W. Hartatik (Editors). Pupuk Kandang. Pupuk Organik dan Pupuk Hayati (Organic Fertilizer andBiofertilizer). Balai Besar Litbang Sumberdaya Lahan Pertanian Badan Penelitian dan Pengembangan Pertanian, Bogor.

Hermawan B., Suhartoyo, H., Anandyawati, Hasanudin \& Murcitro, B.G. (2019). Spatial variability in soil water under adjacent mature oil palm and rubber plantations: application of a new dielectric method in evaluating soil water. IJATAATSEA, 15(2), 261-271.

Jamilah. (2002). Pengaruh Pemberian Pupuk Kandang dan Kelengasan terhadap Perubahan Bahan Organik dan Nitrogen Total Entisol. http://repository. usu.ac.id/bitstream/handle/ 123456789/1133/ tanah-jamilah.pdf. 9 Februari 2019.

Leiwakabessy, F.M., Wahjudin, U.M., \& Suwamo. (2003). Kesuburan Tanah. Jurusan Tanah. Fakultas Pertanian, Institut Pertanian Bogor, Bogor.

Luviana, Marlina, \& Agusni. (2017). Pengaruh konsentrasi dan interval waktu pemberian D.I Grow terhadap pertumbuhan dan produksi Melon (Cucumis melo L). Jurnal Agrotropika Hayati. 4(4), 314-331.

Maryani, A T. (2012). Pengaruh volume pemberian air terhadap pertumbuhan bibit kelapa sawit di pembibitan utama. Jurnal Fakultas Pertanian Universitas Jambi. 1 (2), 64-74.

Muhidin. (2000). Evaluasi toleransi beberapa galur/ varietas kedelai (Glycine $\max (\mathrm{L})$ Merril) terhadap cekaman aluminium. Thesis. Program Pascasarjana, Institut Pertanian Bogor, Bogor.

Prasetyo, B.H. \& Suriadikarta, D.A. (2006). Karakteristik, potensi dan teknologi pengelolaan tanah ultisol untuk pengembangan pertanian lahan kering di Indonesia. Litbang Pertanian. 25(2), 39-47.

Pusat Penelitian Tanah \& Agroklimat. (1994). Survei Tanah Detail di Sebagian Wilayah D.I. Yogyakarta (skala $1: 50.000$ ). Proyek LREP II Part C. Puslittanak, Bogor.

Setyorini, D., Saraswati, R. \& Anwar, E.K. (2006). Kompos. In R. D. M. Simanungkalit, D. A. Suriadikarta, R. Saraswati, D. Setyorini, dan W. Hartatik (Editors). Pupuk Kandang. Pupuk Organik dan Pupuk Hayati (Organic Fertilizer and Biofertilizer). Balai Besar Litbang Sumberdaya Lahan Pertanian, Badan Penelitian dan Pengembangan Pertanian, Bogor.

Simanullang, A.Y, Artha, IN. \& Suwastika, A.A.N.G. (2017). Pengaruh komposisi media tanam dan pemberian pupuk anorganik majemuk terhadap pertumbuhan awal bibit kelapa sawit (Elaeis guineensis Jacq.). E-Jurnal Agroekoteknologi Tropika. 6(2), 178-186.

Simanungkalit, P, Ginting, J. \&Simanungkalit, T. (2013). Respons pertumbuhan dan produksi tanaman melon (Cucumis melo L.) terhadap pemberian pupuk NPK dan pemangkasan buah. Jurnal Online Agroekoteknologi. 1(2), 238-248.

Siswanto. (2010). Monograf meningkatkan Kadar Gula B uah Melon. UPN "Veteran" JawaTimur, Surabaya. 
Song, N. \& Banyo, Y. (2011). Konsentrasi klorofil daun sebagai indikator kekurangan air pada tanaman. Jurnal Ilmiah Sains, 11(2), 169-170. DOI: https://doi. org/10.35799/jis. 11.2.2011. 202.

Subagyo, H., Suharta \& Siswanto, A.B. (2000). Tanah- tanah Pertanian di Indonesia, In Sumberdaya Lahan di Indonesia dan Pengelolaannya. Pusat Penelitian Tanah dan Agroklimat, Bogor.
Sutejo, M.M. \& Kartasapoetra, A.G. (1992). Pupuk dan Cara Pemupukan. Bina Aksara, Jakarta..

Syukur, A. (2005). Pengaruh pemberian bahan organik terhadap sifat-sifat tanah dan pertumbuhan caisin di tanah pasir pantai. J. Ilmu Tanah dan Lingkungan. 5(1), 30-38. 